\title{
The Base of Prosperity in Developing Economies: A Case of Business Enterprises in Nepal
}

\author{
Jit Bahadur K.C. \\ Associate Professor, \\ Nepal Commerce Campus, Faculty of Management, TU. \\ Email: managementtu14@gmail.com
}

\begin{abstract}
Purpose: This article aims to explain the status of BEs and to discuss their role in Nepal for a prosperous nation.

Methods and materials: The study adopts the explanatory methods using both (i.e., primary and secondary) source and secondary data. For this purpose, the study entertained the process of collecting, arranging, organising and interpreting the collected data with appropriate forms.
\end{abstract}

Findings and conclusion: The study found different types and forms of BEs in Nepal with different legal statuses but very small in number. The forms of BEs showed that sole proprietorship and P.Ltd. dominated business culture. Foreign companies and public limited companies which issue shares and debentures found in nominal number. The conclusion of the study shows that the governments of Nepal from the very beggings have not been working in a planned way to established the BEs in the appropriate required forms, types, natures and manner. Considering the requirement of the nation on the BEs, the government of Nepal should immediately take a good step for further development of the BEs.

Originality/value: In this subject and context it is the first attempt although it deals with the BEs with different aspects and explains the role of BEs for the prosperity of the nation very clearly and substantially. However, it requires further study to be completed in all aspects.

Keywords: Business enterprise, proprietorship, partnership, private limited company, public limited company, unlimited liability, limited liability.

\section{Introduction}

Business enterprises (BEs) are vitally important in the development process of a society, nation and region. It is already been proved that BEs are the cornerstone of many aspects of prosperity because they create resources, which ultimately use for human welfare and development. Again, there is a direct relationship between business activities and entrepreneurship. The entrepreneurs develop business activities which activities enhance resource mobilization. Thus, most experts believe that resource mobilization accelerates economic growth which significantly affects the standard of living in the country. Consequently, BEs are the accelerator of the engine for economic growth. However, in the context of Nepal, the World Bank Group (2018) reported that Nepal is one of those countries with very low economic activities and thus one of the very low-income countries in the world. It produces only a few goods and services and relies heavily on imports even for most of the essential goods, it has ever-growing trade deficits also, this is a 
result of Nepal having a very low number of BEs.

This writing evaluates the types of BEs and their importance in nation-building considerably because experts believe that BEs are not only the economic engine (Muske, Woods, Swinney, \& Khoo, 2007) but also the lifeblood for the prosperity of the nation. The literature of BEs shows that there is a significant and inseparable association between the entrepreneurs (EPs) and BEs. The EPs spark economic growth and development, through the starting of new businesses, which in turn creates jobs, links between the markets, produced goods and services, facilitate the welfare of society and pay a considerable amount in taxes to the government.

The BEs can be categorised through different attitudes such as by size, activities, forms of property and organizational-legal forms/standards. In this respect, the economic theory suggests that the criteria of the production of goods or services; independence; the purpose of getting profits; registration following legislation; organization and autonomic governance; the presence of employees and working facilities.

In this $21^{\text {st }}$ century, BEs are not just one of the vehicles of economic activities and economic growth of a community, region or state, but also a base for the human welfare in the entire world. Thus, we tried to explain the categories and their importance in the national economy and overall knowledge about the BEs in the context of Nepal through this article.

\section{Problems}

Many countries, mostly the developing countries of the third world have been suffering from various issues while developing their infrastructure in this $21^{\text {st }}$ century too. They are unable to use their available resources efficiently for human welfare. It means that their skill, technology and existing system are not functioning properly. To tackle such issues, countries need to bring reforms and introduce policies to encourage entrepreneurship and the establishment of BEs of various types, kinds, forms and sizes. However, one has to consider yet another issue in this regard, the EPs wish to run the business solely for their own interests only, which can be harmful to some extent. For example, Serafeim (2014) viewed that a long-standing ideology in a business traditionally has been running for the sole interest of its owners. Nevertheless, the BEs should run in the national interest to provide opportunities, direct and indirect employment, goods and services, revenue to the government and for efficient use of the available resources of the nation. In Nepal, such activities fall in the lowest choice in the case of doing business (The World Bank, 2018). Experience proves that most Nepali uses goods produced from abroad in their kitchen to bathroom and from birth to death. On other hand, every buyer feels trading business everywhere of the similar products with the domination of the small-scale business of sole proprietorship, then mostly, neither they produce goods and services, nor they create jobs in the society as required by the nation. Thus, in this regard, we tried to explain some types of BEs and their significant role in the prosperity of Nepal.

\section{Objectives}

The foremost objective of this article is to explain the types of BEs and their role in nation-building. The subsidiary objectives of the article are as follows:

- To explain the status, types and forms of BEs and

- To discuss the role of the BEs in economic growth prosper a nation.

\section{Significance and Limitations}

This type of writing is the first and single attempt in this subjective view. Consequently, it has separate importance. Thus, this writing is significant for those persons who are willing to gain knowledge about the types, kinds and categories of BEs and their role in the economic prosperity of the nation. Academically and practically, it is useful to the teachers, lawyers, auditors, accountants, policymakers, experts, students and so on. 


\section{Review of Related Literature}

The review of related literature is to demonstrate an understanding of theories and concepts that are relevant to the research and that relate to the broader areas of knowledge (K.C., 2017). Thus, this section describes the fundamental and theoretical view of BEs, which exist in the prevailing system irrespective of the forms of BEs.

$\mathrm{BE}$ is an endeavor where the foremost motive is profit and not mere employment for oneself and others. The single term "business" refers to the organized effort of individuals to produce and sell, for a profit, the goods and services that satisfy society's needs. Davis (2018) demarketed, "A business, then, is an organization, which seeks to make a profit through individuals working toward common goals". The goals of the business will vary based on the type of business and business strategy. Regardless of the preferred strategy, businesses must provide a service, product, or goods that meet a need of society. In the same way, the term "enterprise" refers to organized business activities aimed specifically at growth and profit for the investor/s. OECD (2006) outlined the term "enterprise" in the following words:

An enterprise is a term in the commercial world used to describe a project or venture undertaken for gain. It is often used the word "business" as in 'business enterprise'. Usually, by extension, it refers to the business entity carrying out the enterprise and is thus synonymous with the undertaking, company or firm.

Thus, a BE is considered as any firm or entity engaged in economic activity, irrespective of its legal form.

Enterprises are also either formal or informal. The term enterprise is mostly used for informal entrepreneurial activities. Kokemuller (2018) viewed that any type of sole proprietorship is considered an individual's informal business because that may be set up ignoring a legal aspect of business operation while formal enterprises include partnerships, S-corporations, limited liability companies, corporations and joint ventures.

The BEs consist of several characteristics according to their nature and objectives. They are: (i) economic activity, (ii) buying and selling, (iii) continuous process, (iv) profit motive, (v) risk and uncertainties, (vi) creative and dynamic, (vii) customer satisfaction, (viii) social activity, (ix) government control and (x) optimum utilisation of resources.

Similarly, a BE encompasses some major and minor objectives. However, the experts of EPs classify them into five major objectives (i.e., economic objectives, social objectives and human objectives, including national objectives and global objectives). Each of the said five objectives include various sub-objectives as shown in figure 1 .

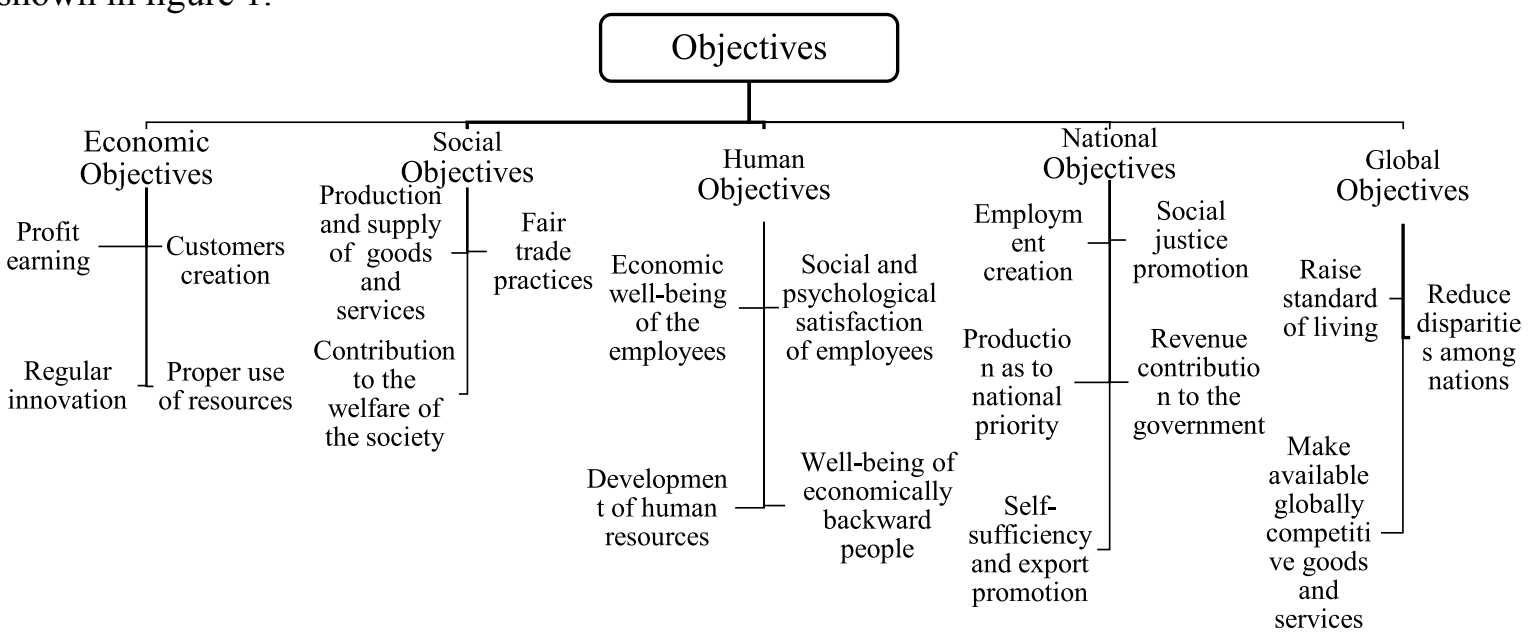

Fig. 1 Objectives of the BEs

According to the literature, there are several types of BEs in the world. Normally, their incorporation bases on different elements and their basic legislation conducted in their countries. For example, a corporation 
is a type of company while not all companies are corporations. Again, corporations are quite different from sole proprietorship, partnership and limited liability companies. Measures (2017) distinguished that sole proprietors, partnerships and limited liability companies in terms of structure and decision-making methods.

The BEs can be commonly categorized into the following: sole proprietorship, partnership, limited partnership, limited liability company, company/corporation (both profit-making and non-profit-making) and cooperative. Sole proprietorship and general partnership are the most common forms of business structure, but companies and corporations are different and difficult forms of BEs. They are different in the following respects.

Table 1

Difference between the different BEs

\begin{tabular}{|c|c|c|c|c|}
\hline BEs & Incorporation & Status of BEs & Financial operation & Tax liabilities \\
\hline $\begin{array}{l}\text { Sole } \\
\text { proprietor }\end{array}$ & $\begin{array}{l}\text { Firm's registration } \\
\text { act }\end{array}$ & $\begin{array}{l}\text { The identical status } \\
\text { between owner and } \\
\text { business }\end{array}$ & $\begin{array}{l}\text { All financial matters } \\
\text { regard as personal } \\
\text { matters. }\end{array}$ & $\begin{array}{l}\text { The owner is } \\
\text { responsible for the tax } \\
\text { liabilities }\end{array}$ \\
\hline Partnership & Partnership deed & $\begin{array}{l}\text { Decides } \\
\text { partnership deed }\end{array}$ & $\begin{array}{l}\text { The partners take their } \\
\text { risks as to their share in } \\
\text { the business. }\end{array}$ & $\begin{array}{l}\text { Each partner pays } \\
\text { their taxes separately }\end{array}$ \\
\hline Corporation & $\begin{array}{l}\text { Chartered or } \\
\text { corporate act and } \\
\text { involves a board of } \\
\text { directors }\end{array}$ & $\begin{array}{l}\text { Legally exists } \\
\text { separately from its } \\
\text { owner(s). }\end{array}$ & $\begin{array}{l}\text { Financial operation } \\
\text { conducts from the name } \\
\text { of the corporation }\end{array}$ & $\begin{array}{l}\text { Imposes taxes in the } \\
\text { name of corporations. }\end{array}$ \\
\hline $\begin{array}{l}\text { Limited } \\
\text { liability } \\
\text { company }\end{array}$ & $\begin{array}{l}\text { Neither partnership } \\
\text { nor corporation. }\end{array}$ & $\begin{array}{l}\text { Liable either by } \\
\text { members or by a } \\
\text { manager. }\end{array}$ & $\begin{array}{l}\text { It protects some } \\
\text { liabilities of the } \\
\text { individual assets. }\end{array}$ & $\begin{array}{l}\text { Imposes taxes on the } \\
\text { name of the company. }\end{array}$ \\
\hline $\begin{array}{l}\text { Limited } \\
\text { Company }\end{array}$ & $\begin{array}{l}\text { A separate legal } \\
\text { entity }\end{array}$ & $\begin{array}{l}\text { Liability including } \\
\text { debts limited up to } \\
\text { the shares }\end{array}$ & $\begin{array}{l}\text { Operates in the name of } \\
\text { the company }\end{array}$ & $\begin{array}{l}\text { Determines the tax } \\
\text { liability in the name } \\
\text { of Companies. }\end{array}$ \\
\hline
\end{tabular}

According to the nature and forms of the BEs, the sole proprietorship businesses are personal and partnerships run as per the partnership deed while corporations and companies legally exist as a legal person and are liable up to their invested capital.

The legal status of the BEs is the prerequisite to determine the types of BEs and the numbers of the owners or the amount of money to be invested (Layne, 2017).

Muske, Woods, Swinney and Khoo (2007) stated that the small-scale industries contribute a considerable amount of gross income and employment in a community, which may be a base for the national economy. Similarly, Kunz (2017) evaluated that beyond the difference in structure and management, corporations and partnerships are taxed differently and they include different start-up costs. Generally, companies and corporations are the more expensive and complicated structure of business compared to the sole proprietorship and partnership or other forms of BEs.

Huebsch (2017) asserted that the structure and the types of BE substantially differ in tax obligations. In the same way, Joyner (2017) discussed the use of an accounting system in different BE differs considerably. The accounting of corporations and companies differs from that of partnership and proprietorship.

In the case of Nepal, K.C. (2007) highlighted that corporations and companies must adopt the accrual method of accounting while partnership and proprietorship can choose either of the methods of accounting 
(i.e., cash or accrual).

We discussed the framework of the study, which shows the gap of knowledge for the BEs and their role in the prosperity of the nation in the context of Nepal. Thus, we tried to explain and discuss the types and their roles in Nepal.

\section{Methods and Materials}

The methodology is the basic part of all academic writing. By nature and scope, this writing adopts explanatory methods based on the non-quantitative approach to explain the phenomenon on the types, categories, forms and attitudes of the established BEs in Nepal. As a result, this article uses both primary and secondary sources of information and data. Considering the various factors, we used books, journals, reports, bulletins, records, websites, etc.

In the first phase, we collected the data and information from the previously mentioned sources and in the second phase, they were arranged, classified and tabulated in the appropriate form as shown in the tables and figures. Moreover, in some cases, we attempted a telephone inquiry to verify the data to make them valid and reliable as to the norms of research to get the truth and fact.

\section{Results and Discussion}

This section is the most important part of the article consequently it incorporates the results, discussion and finding in the following section/s.

\section{Status, Types, and Forms of BEs in Nepal}

It discusses the total number of BEs and their types, kinds and categories considering their norms, values and characteristics. Thus, we rigorously discuss each of them in the following sections.

\section{Number of BEs in Nepal}

Based on the best countries in the world of business, Nepal ranks 116 out of 161 selected countries of the world. To put the grim state of the economic state of Nepal into perspective, Bangladesh, another South Asian country fares much better in this regard, the same is $109^{\text {th }}$ in position (Forbes, 2019). The given below figure discloses the status of the businesses and their types of BEs in Nepal.

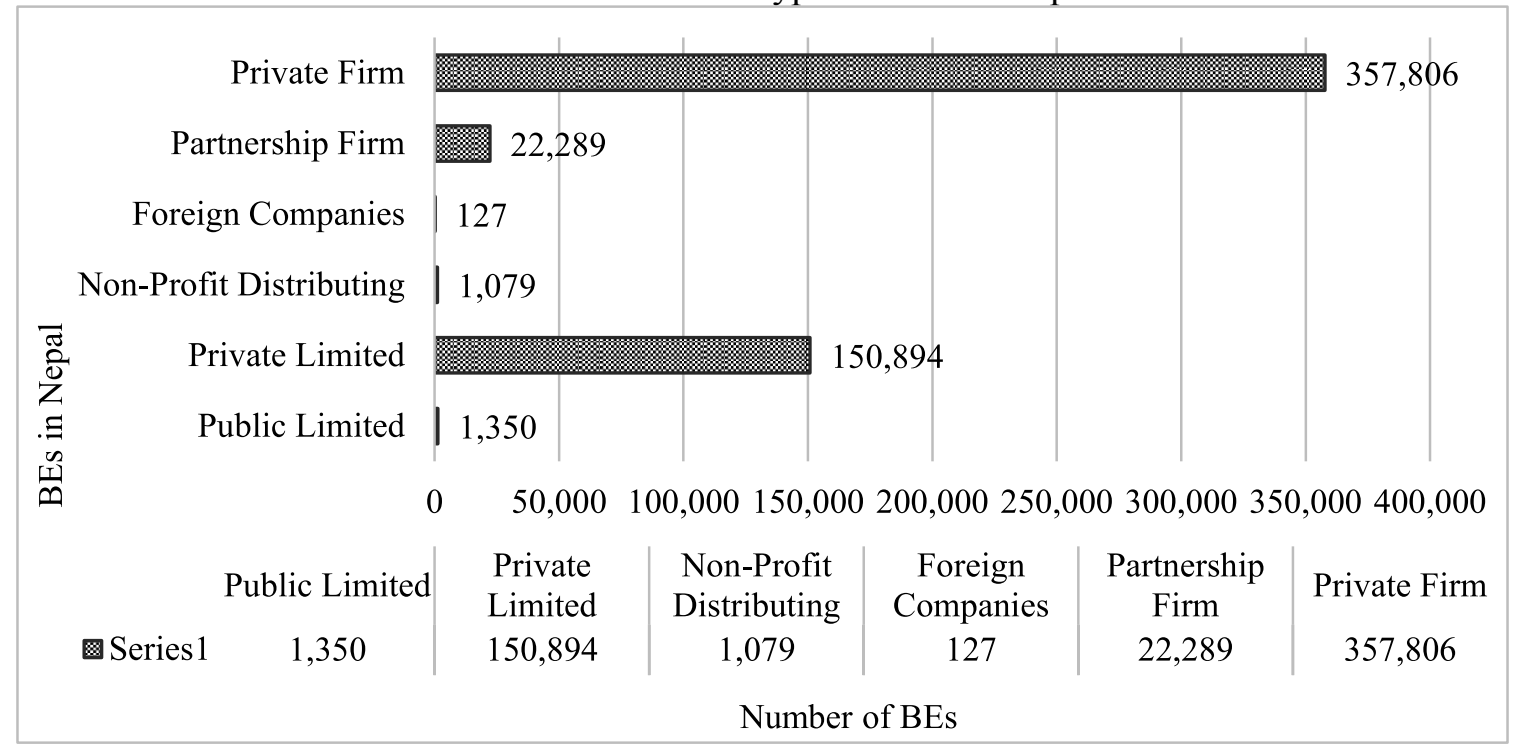

Fig. 2 BEs in Nepal

Source: 1. Office of the Company Registrar, 2073

2. Economic Survey, 2075 


\section{Issue 1 May/June 2020}

The above-presented data revealed that Nepal has 533,545 numbers of BEs comprising $67.06 \%$ of private firms and $28.28 \%$ of private limited (P. Ltd.) Companies. However, other forms of BEs hold only $4.66 \%$, which is quite low in number. There are only 1,350 public limited companies, which have the right to issue debentures and equity shares to the public and able to list on Nepal Stock Exchange Limited.

\section{BEs Based on Capital and Production of Goods and Services in Nepal}

BEs are the vehicles of economic growth while EPs are key drivers for the operation and investment of the businesses. It is obvious that without EPs, the business cannot emerge and without business, neither the government can receive the tax and the EPs earn the profit nor can the society reap the benefits. According to the Industrial Enterprises Act, Nepal holds the following types of BEs based on fixed capital and production of goods and services.

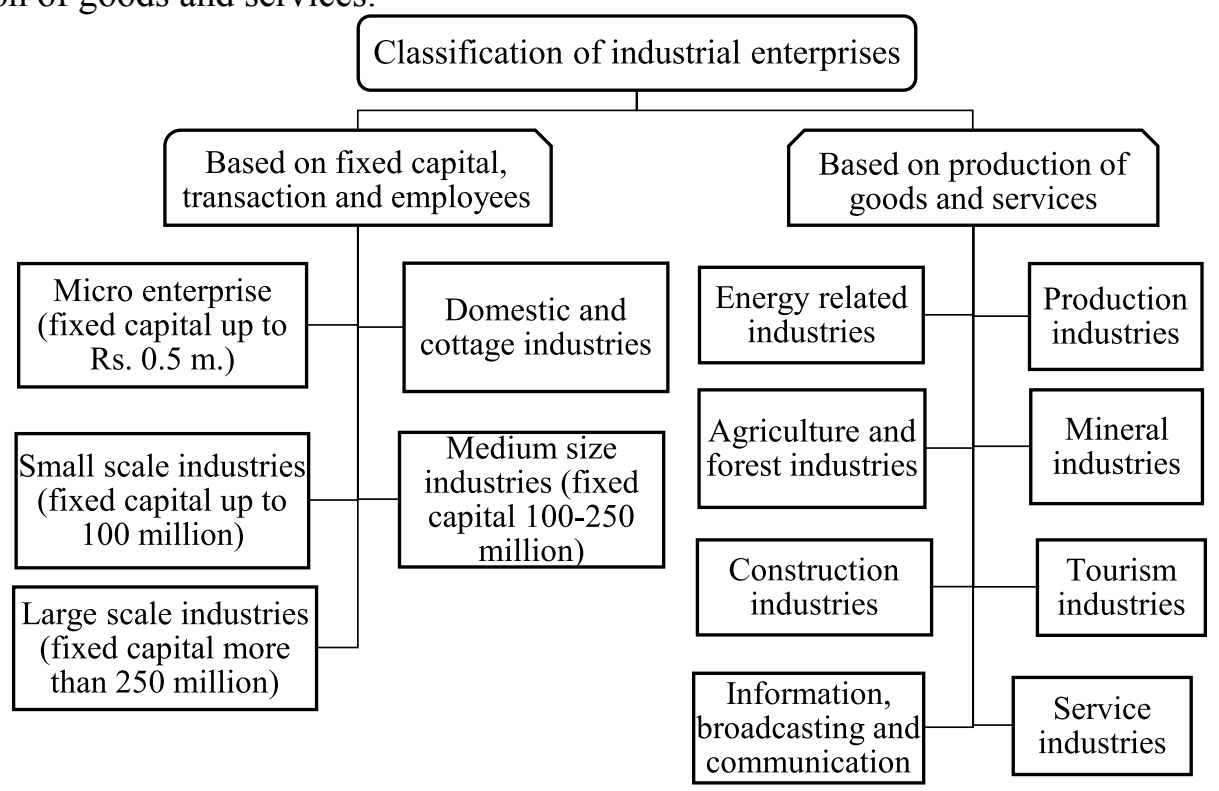

Fig. 3 Classification of BEs based on the fixed capital and goods and services

\section{BEs Based on the Production of Goods/Service and Ownership or Liabilities}

Businesses are the cornerstone of economic activities to accelerate economic growth while EPs are key players in financing the BEs. In this context, Nepal holds the following types of BEs based on activities and ownership or liabilities.

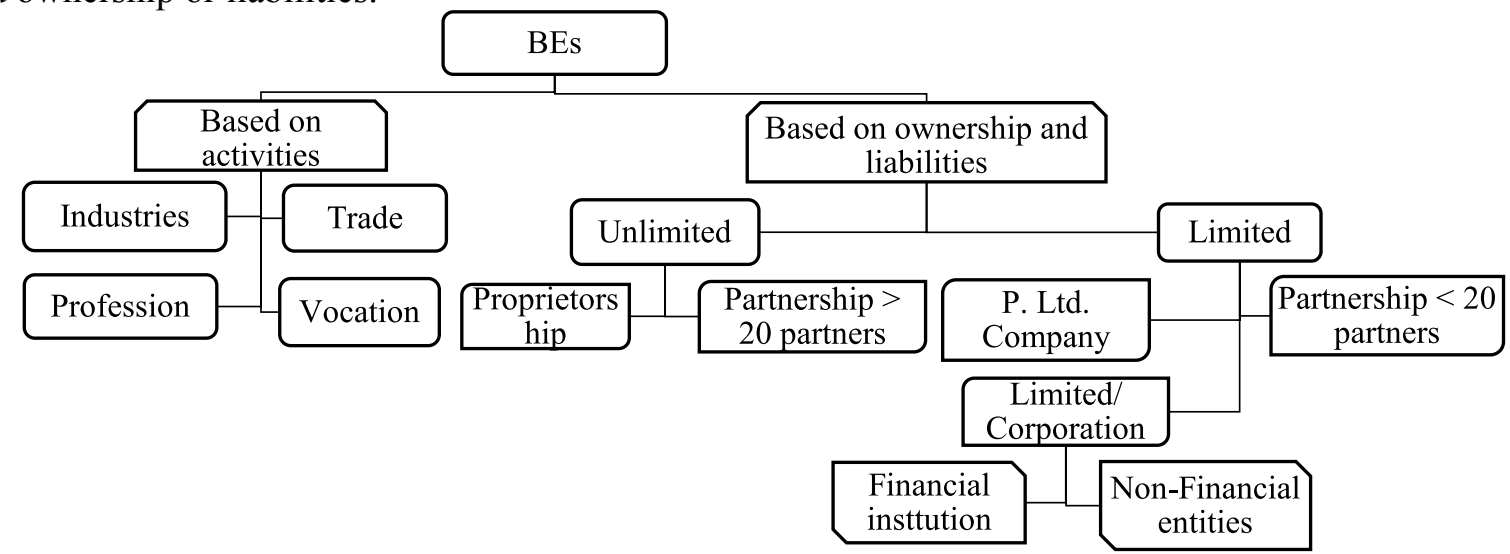

Fig. 4 Types of BEs based for tax purposes

Source: Authors elaboration based on K.C. (2007) 
Based on the argument of activities, there are four types of BEs. It means that a BE may be either industry or business or profession or vocation. Similarly, based on ownership or liabilities, the BEs are two types of unlimited and limited liabilities. The BEs of unlimited liabilities are proprietorship and general partnership while the P. Ltd. company, limited company, and partnership with more than 20 partners fall under the category of limited liabilities. Besides limited companies are also of two categories (i.e., financial and non-financial).

\section{BEs Based on Different Aspects}

The enforceable or prevailing laws determine the size and types of the company in any country. According to the prevailing Company Act, Nepal includes the following types of companies as shown in figure 4.
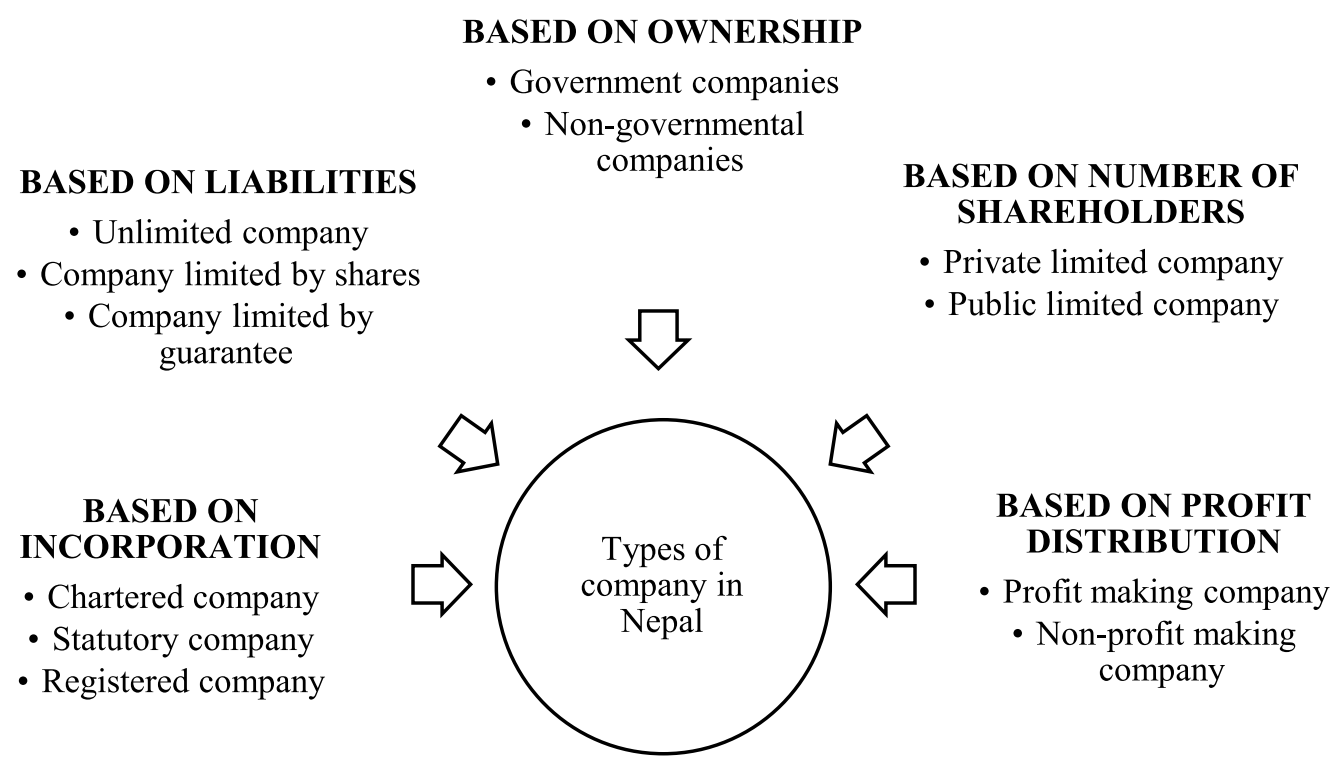

Fig. 5 Types of Companies in Nepal

Sources: Authors elaboration, 2019

The above-presented figure shows the various types of companies under each base, we discuss them briefly in the following paragraphs.

\section{Based on incorporation}

Based on the incorporation, the companies of Nepal are three types. They are: (i) chartered, (ii) statutory and (iii) registered.

\section{Chartered company/corporations}

As its name suggests, these are the companies incorporated under a chartered act / a special act, which enact by the state. For example, Nepal Telecom Corporation (NTC), Royal Nepal Airlines Corporation (then RNAC) and now Nepal airlines (NAC) are the corporations incorporated by the chartered acts. The charm of such types of companies is equally important to date as they were at the time of incorporation.

\section{Statutory company}

A company, which is incorporated through a special act, is called a statutory company in Nepal. The act always defines its objectives, powers and activities to be adopted while running the company. Nepal Rastra Bank (NRB), Agriculture Development Bank Limited (ADBL), Nepal Industrial Development Corporation (NIDC) and later NIDC development Bank (Rashtriya Banijya Bank Limited have been acquired now) are 
some examples of the statutory corporations.

\section{Registered company}

Registered companies or corporations are those, which incorporated under the company act of the country. The prevailing Companies Act governs the working of a registered company. For example, Gorkha Biscuits P. Ltd. is one of the registered companies in Nepal.

\section{Based on liability}

Based on liabilities, there are three types of companies. Those are the unlimited company, a company limited by shares and companies limited by guarantee.

\section{Unlimited companies}

The unlimited companies or corporations are those in which the liability of the members is unlimited, similar to that of a partnership firm. If the assets of the company are not sufficient for satisfying the claims of the creditors, the shareholders are liable to pay more than the face or nominal value of shares held by them, even if it is paid from their estate. It may be any percentage of the held shares in the business.

\section{Companies limited by shares}

The Company limited by shares is that by which the provisions of the Company Act with a specific amount of share capital divided into a definite number of shares. The liability of shareholders is limited to the extent of the face value of the shares held by them. This type of company is quite common at present.

\section{Companies limited by guarantee}

The Company, under which each shareholder promises to pay a specific sum as a guarantee at the time of winding up of a company, is called a company limited by guarantee. The Memorandum of Association of the Company specifies such guarantees. The amount of such a guarantee may differ from member to member.

\section{Based on ownership}

There are two types of business entities based on ownership (i.e., Government companies and nongovernment companies).

\section{Government companies}

There are two types of government companies: (i) fully owned and (ii) partially owned. The former type of business organization is that in which the government owns all the shares of the company. The latter is one in which the government holds $51 \%$ of the paid-up share capital, but in some cases, the government may hold less than $51 \%$ too.

\section{Non-government companies}

An establishment, which is not a government undertaking, is called a Non-government Company. Generally, the Company owned, managed and controlled by the private sector falls under this category in Nepal.

\section{Based on the number of members}

The Company or corporation can be categorized based on the number of members' involvement in the undertakings. According to these categories, a company may be either private or public companies. 
Private companies

A private company is that which by its Memorandum of Association limits the number of its members. In Nepal, the private company may have up to 50 members. It prohibits the issue of shares and debentures to the public. A private company must include the words P. Ltd. in its name. P. Ltd. can entertain the following privileges:

It can be established by a person or group of persons (not more than 50 persons signing an agreement);

It does not need to publish a prospectus at the time of issue of its shares;

It can refuse the transfer of shares from one member to another;

O Such a company doesn't need to obtain the certificate of commencement of business before starting its business activities;

It is not necessary to hold a statutory meeting (if a single person holds the company).

\section{Public companies}

A public company is that which needs its own Memorandum of Association and Article of Association. It must have at least seven members, but there is no upper limit regarding the maximum number of members. It can sell its shares to the public, but rather it allows collecting major capital by offering shares to the public and also able to issue the debenture. The public company is governed by the authorized capital, which is registered and the issued shares are transferable. A public company must use the word limited (Ltd.) in its name. The public company can take the following privileges:

It is possible to establish this type of company by seven or more promoters;

$\bigcirc \quad$ It needs to publish a prospectus at the time of issue of its shares;

It facilitates to transfer of shares from one member to another;

$\mathrm{O}$ Such a company must obtain the certificate of commencement of business before starting its business activities;

O It is necessary to hold a statutory meeting (i.e., board meetings and annual general meetings).

\section{Based on profit distribution}

The companies of Nepal can be also categorized based on profit-making or sharing and non-profit making (social work doing).

Profit-making

Profit-making companies are those, which distribute the profit to their shareholders from the earnings of the companies.

\section{Non-profit making}

Non-profit making companies are those, which do not distribute their profit or surplus to their shareholders from their earning. These types of business entities concern the social motive and the company status remains as a trust.

A "Not-for-Profit" organization is a group, which is organized for social, religious, charitable, educational, athletic, literary, and political or other such activities. The promoters of the non-profit-making undertakings should consider some points while incorporation such an organization. They are a distinct legal entity, limited liability, perpetual existence, ownership of property, and government aid.

\section{Role of BEs in Economic Growth}

BEs play a significant role in promoting the economic growth of a nation. Experts believe that BEs contribute to the national or international economy in the following ways: 


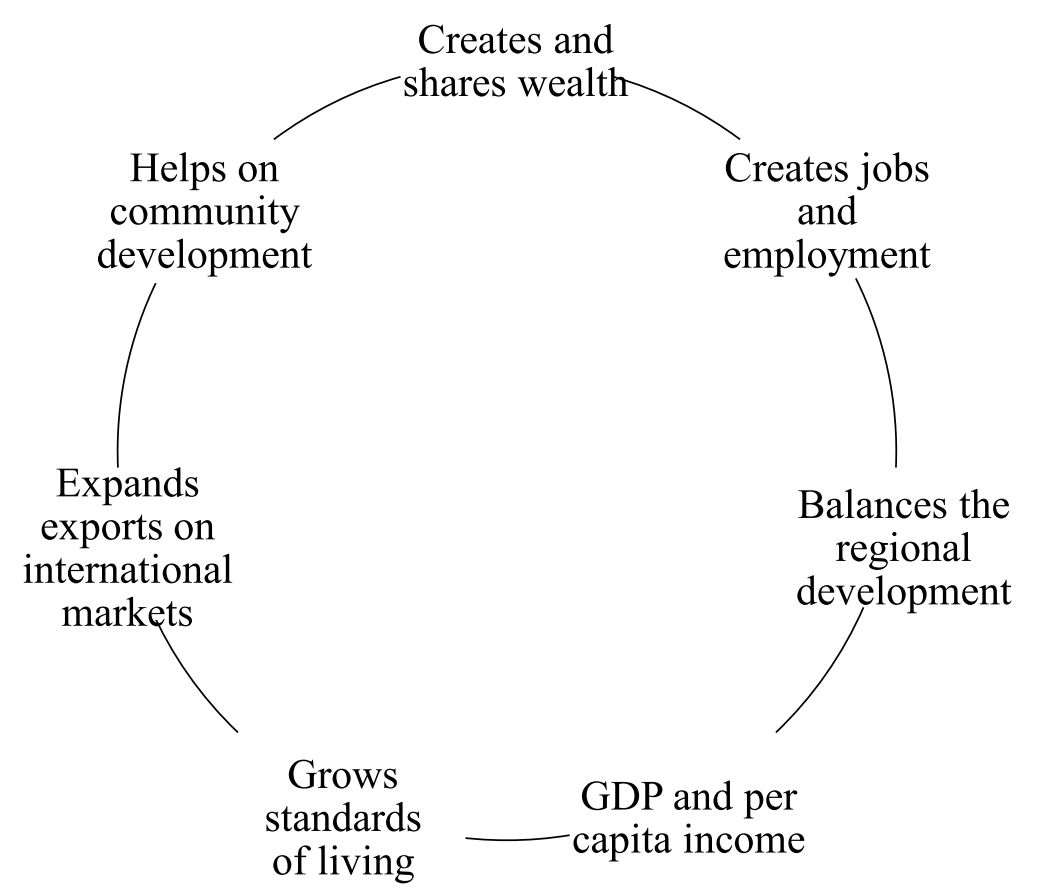

Fig. 6 Role of business enterprises

\section{Business Creates and Shares the Wealth}

Most of the EPs invest their capital to flourish their business entity and use other capital (i.e., in the form of debt capital too). Such types of activities play a role in pooled capital that normally results in wealth creation and distribution, which are the basic steps of economic development.

\section{Creates Jobs and Employment}

EPs are the job creators. Creating more and better quality jobs is key to boosting growth, reducing poverty and increasing social cohesion. At the national level, job creation requires a stable macroeconomic framework coupled with structural policies that encourage innovation, skills and business development.

\section{Business Balances the Regional Development}

EPs set up new businesses and industrial units in a community, which helps to balance the regional development because most of the EPs desire to set up the business in backward areas (to avail tax benefits). The establishment of a new business brings improvement of infrastructures such as road links, airports, electricity, water supply, schools, hospitals and different types of public and private service facilities. These elements normally improve the standard of living in society. Normally, new businesses provide opportunities to the citizens, increase government revenue, support development activities and facilitate several items of services.

\section{GDP and Per Capita Income}

Every business is the cornerstone of development. The use of resources like land, labour and capital to develop the products and services that add to the national income, gross domestic products and per capita income of the nation. The growth in these elements is the essential element of economic growth. 


\section{Standards of Living}

Increasing the standard of living of the people in a community is the main goal of economic growth, which is possible only through the proper use of the land, labour and capital in a community. The work of EPs is to create jobs, opportunities, make innovations and improvement in the quality of life.

\section{Exports and International Markets}

The international market consumes a higher quality and quantity of goods consequently; the EPs, which produce the goods and services for the international markets, can earn a huge profit. Consequently, new opportunities arise for businesses in society.

\section{Community Development}

Community development depends on the skilled workforce too. If there is a good infrastructure of all the elements like education, training, health centre, technical schools in a community, then those attract businesses and activities of entrepreneurship and bring economic growth as a whole.

Therefore, there is a significant role of EPs to spark economic growth and development, which start new businesses, creating jobs, and contributing to improvements in various key goals. For instance, economic growth, exports, the standard of living, skills development and community development.

Thus, the EPs conduct businesses, such economic activities offer job opportunities in the community, provide goods, and services in domestic as well internationally, pay huge amount of revenue to the government and bring technology and skill in the domestic market. Hence, businesses are the vehicles of economic growth, development and base of overall development for human prosperity in the entire world.

Government Efforts for the Industrialisation

Considering the crucial importance of BEs in the overall development of the nation, the government of Nepal tried to establish adequate numbers and forms of BEs post-referendum in Nepal. The following table highlights the year of establishment of the industrial estate, assistance and employment capacity under the state.

Table 2

Comprehensive details of the industrial estate

\begin{tabular}{llcccc}
\hline \multicolumn{2}{l}{ Industrial estate } & Year & Assistance & Employment & \% of total employment \\
\hline 1 & Balaju & 1960 & USA & 4,100 & 24.07 \\
2 & Patan & 1963 & India & 2,000 & 11.74 \\
3 & Hetauda & 1963 & USA & 4,000 & 23.48 \\
4 & Dharan & 1973 & India & 900 & 5.28 \\
5 & Nepalgunj & 1973 & India & 994 & 5.83 \\
6 & Pokhara & 1974 & Nepal & 2,298 & 13.49 \\
7 & Butwal & 1976 & Nepal & 1,617 & 9.49 \\
8 & Bhaktapur & 1979 & Germany & 800 & 4.70 \\
9 & Birendra Nagar & 1981 & Netherlands & 300 & 1.76 \\
10 & Gajendra Narayan Singh & 1983 & India & 28 & 0.16 \\
& Total & & 17,037 & 100.00 \\
\hline
\end{tabular}

Source: Economic Survey, (2075)

In 1960, the United States of America established the Balaju Industrial Estate for several BEs, which is the largest industrial estate in terms of employment and is capable of the 4100 direct employment. Nepal continued this process of establishment until 1983 and reached 10 industrial estates with a direct employment capacity of 17037 persons. In 1990, Nepal restored a democratic government than some public 
enterprises sold to the private sector and stopped the process of establishment of the industrial estate in Nepal until to date.

\section{Conclusion}

Nepal is a landlocked and mountainous country. Thus, its rapid economic development is a difficult task because the development infrastructure requires a huge amount of capital funds, which is inadequate and scarce in Nepal.

There are very few public limited companies (1350) in Nepal. It suggests a lack of proper knowledge in raising capital through public issues of shares, widening the shareholder base, spreading risk, and growth and expansion opportunities. Consequently, there developed a large number of firms (i.e., P. Ltd. Company and private firm).

Nepal established BEs of different legal statuses (i.e., proprietorship, partnership, company, corporation, unlimited liability, limited liability, governmental, non-governmental, profit-making, nonprofit making, etc.,), their number is very small and most of them are sole proprietorship businesses. The evidence shows that private firms run to own their interest, but BEs should keep into consideration the national interests as well.

The government should consider the value of the BEs and their role considerably to make progress in the economic prosperity of the nation, which requires significant reform in the existing policies and programs of the government.

\section{Scope for Future Research}

The reaserch writing is a complicated work. It requires systematic evaluation, valuation, assessement and rigorous experience and thought. But, due to the lack of adequate information and literature on the subject, it could not be tested and evaluated well. Thus, it is suggested for further study to provide new knowledge on the subject.

\section{References}

Davis, B. (2018, January 31). What is a business? Definition, characteristics and examples. Retrieved from Study.Com: https://study.com/academy/lesson/what-is-a-business-definition-characteristicsexamples.html

Forbes. (2019, February 27). Best countries for business - 2018 ranking. Retrieved from Forbes Media LLC: https://www.forbes.com/best-countries-for-business/list/4/\#tab:overall

Huebsch, R. (2017, December 13). The difference between corporations, LLC, and partnership. Retrieved from Chron: http://smallbusiness.chron.com/difference-between-corporation-llc-partnership-3989. html

Joyner, J. (2017, December 12). Accounting difference for a partnership \& corporation. Retrieved from Chron: http://smallbusiness.chron.com/accounting-difference-partnership-corporation-66325.html

K.C., J. B. (2007). Tax laws and tax planning: Theory and practice. Kathmandu: Khanal Book Prakashan. K.C., J. B. (2017). Presumptive income taxation in Nepal: A critical analysis. Kathmandu: Maya Khadka. Kokemuller, N. (2018, January 17). Organization vs. enterprise. Retrieved from Chron: https://smallbusiness. chron.com/organization-vs-enterprise-68475.html

Kunz, M. (2017, December 13). Major differences between a corporation and a partnership. Retrieved from Chron: http://smallbusiness.chron.com/5-major-differences-between-corporation-partnership-18830. html

Layne, E. (2017, December 13). The difference between Inc. \& Ltd. \& Co. Retrieved from Chron: http:// smallbusiness.chron.com/difference-between-inc-ltd-co-38627.html

Measures, A. (2017, December 13). The difference between a corporation and a company. Retrieved from Chron: http://smallbusiness.chron.com/difference-between-corporation-company-5182.html

MOF. (2075). Economic survey, 2075. Kathmandu: Ministry of Finance, the Government of Nepal. 
Muske, G., Woods, M., Swinney, J., \& Khoo, C.-L. (2007). Small businesses and the community: Their role and importance within a state's economy. Journal of Extension, $X X X X V(1)$. Retrieved from https:// www.joe.org/joe/2007february/rb4.php

OECD. (2006, January 2). Business enterprise. Retrieved from Glossary of statistical terms: https://stats. oecd.org/glossary/detail.asp?ID=3207

Serafeim, G. (2014). The role of the corporation in society: An alternative view and opportunities future research. Harvard: Harvard Business Review.

The World Bank. (2018, January 2). Doing business: Measuring business regulations. Retrieved from The World Bank: IBRD - IDA: http://www.doingbusiness.org/data/exploreeconomies/nepal

World Bank Group. (2018). Doing business 2018: Reforming to create jobs. Kathmandu: World Bank Group. 
Issue 1 May/June 2020 - 